\title{
Pembinaan Narapidana Wanita di Lembaga Pemasyarakatan Kelas IIb Dompu
}

\author{
Suherman \\ STKIP Taman Siswa Bima \\ suherman_sh.mdjafar@yahoo.com
}

\begin{abstract}
ABSTRAK
Tujuan dari penelitian ini adalah sebagai berikut: 1. Untuk mengetahui dan menganalisa model pembinaan yang dilakukan di Lembaga Pemasyarakatan terhadap Narapidana Wanita. 2. Untuk mengetahui dan menganalisa faktor Apa Sajakah yang menjadi Penghambat pelaksanaan pembinaan Narapidana Wanita dan Upaya-upaya apa sajakah yang dilakukan oleh Lembaga Pemasyarakatan Kelas IIB Dompu dalam dalam mengatasi hambatan-hambatan yang dihadapi. Jenis penelitian yang digunakan adalah Penelitian Yuridis Empiris, yaitu suatu metode penelitian hukum yang berfungsi untuk melihat hukum dalam artian nyata dan meneliti bagaimana bekerjanya hukum di lingkungan masyarakat. Dikarenakan dalam penelitian ini meneliti orang dalam hubungan hidup di masyarakat maka metode penelitian hukum yuridis empiris dapat dikatakan sebagai penelitian sosiologi hukum karena untuk melihat aspek-aspek hukum dalam interaksi sosial didalam masyarakat, dan berfungsi sebagai penunjang untuk mengidentifikasi dan mengklarifikasi temuan bahan non hukum bagi keperluan penelitian atau penulisan hukum. Dari hasil penelitian, menunjukkan bahwa pembinaan Narapidnaa wanita di Lembaga Pemasyarakatan Kelas IIB Dompu sesuai dengan Keputusan Menteri Kehakiman Republik Indonesia Nomor: M.02-PK.04.10 Tahun 1990 Tentang Pola Pembinaan Narapidana dan Tahanan serta Undang-undang Nomor 12 Tahun 1995 Tentang Pemasyarakatan. Hanya saja pelaksanaannya belum terlaksana secara optimal yang disebabkan beberapa hal, yaitu: Kualitas Sumber Daya Manusia, Kurangnya Kerja sama dengan Pihak ketiga, serta sarana dan prasarana yang belum memadai serta beberapa faktor penghambat pelaksanaan Pembinaan yaitu: Faktor Intern (Sarana Gedung Lapas, Kualitas dan Kuantitas Petugas, Kesejahtreaan Petugas, Sarana/Fasilitas, Anggaran Lapas, SDM, Ragam Program Pembinaan) serta Faktor Intern (Faktor Ekonomi, Faktor Pendidikan). Untuk itu disarankan kepada Lembaga Pemasyarakatan Kelas IIB Dompu untuk lebih meningkatkan Sumber Daya Manusia bagi para Petugas/Pegawai Lembaga Pemasyarakatan tersebut dengan berbagai macam pelatihanpelatihan, serta melaksanakan pembinaan secara optimal sesuai dengan aturan-aturan yang berlaku di jajaran Direktorat Jenderal Pemasyarakatan, dan diharapkan kepada pemerintah pusat untuk membetuk peraturan-peraturan yang khusus dalam mengatur tentang pembinaan Narapidana wanita agar tepat sasaran
\end{abstract}

Kata kunci: Pembinaan, Narapidana Wanita, Lembaga Pemasyarakatan Kelas IIB Dompu

\section{PENDAHULUAN}

Dahulu, jenis hukuman masih bersifat pidana fisik, misalnya pidana cambuk, potong tangan dan bahkan pidana mati (pemenggalan kepala) atau digantung. Dengan lahirnya pidana hilang kemerdekaan, hukuman berubah menjadi pidana penjara selama waktu yang ditentukan oleh Hakim. Seiring dengan itu, eksistensi bangunan tempat penahanan sementara semakin diperlukan, apalagi dengan adanya pidana pencabutan kemerdekaan untuk waktu yang ditentukan oleh hakim tersebut yang tentunya memerlukan waktu yang lama, sehingga diperlukan wadah atau tempat untuk menahan pelaku tindak pidana

Berbicara tentang penjara, di Indonesia secara kronologisnya sudah ada sejak zaman Belanda. Ini dapat dirujuk pada Destichten Reglement Tahun 1917. Dalam Pasal 28 ayat (1) Reglement tersebut dinyatakan bahwa: Penjara adalah tempat pembalasan yang setimpal atas suatu perbuatan atau tindak pidana yang telah dilakukan oleh si pelaku tindak pidana dan juga sebagai tempat pembinaan terhadap narapidana atau pelaku tindak pidana "Tujuan pidana penjara tersebut adalah pembalasan yang 
setimpal dengan mempertahankan sifat dari pidana penjaranya" yang harus diutamakan, tetapi pada akhir Tahun 1963 yang dinyatakan bahwa pidana penjara adalah pemasyarakatan dan hak tersebut lebih mengarah atau mengutamakan "pembinaan" (re-educatie and resocialisatie). Sebenarnya "pemasyarakatan" tersebut bisa diartikan secara umum memasyarakatkan kembali seorang pelaku tindak pidana yang selama ini salah jalan dan merugikan orang lain/masyarakat dan mengembalikannya kembali kejalan yang benar dengan cara membina orang yang bersangkutan tersebut sehingga menguntungkan atau berguna bagi orang lain/masyarakat pada umumnya.

Selanjutnya, sistem Pemasyarakatan yang sudah dilaksanakan sejak Tahun 1964 tersebut harus ditunjang oleh payung hukum supaya lebih berarti keberadaannya yaitu Undangundang nomor 12 Tahun 1995 tentang Pemasyarakatan. UU Pemasyarakatan tersebut menguatkan usaha-usaha untuk mewujudkan suatu sistem Pemasyarakatan yang merupakan tatanan pembinaan bagi Warga Binaan Pemasyarakatan..

Dalam melakukan pembinaan terhadap narapidana Wanita, harus dibedakan dengan pembinaan terhadap Narapidana Pria karena wanita mempunyai perbedaan baik secara fisik maupun psikologis, hal ini diatur dalam Pasal 12 ayat 1 dan 2 Undang-undang Nomor 12 Tahun 1995:

Ayat 1: Dalam rangka pembinaan terhadap Narapidana di Lembaga Pemasyarakatan dilakukan penggolongan atas dasar; a. Umur, b. Jenis kelamin, c. Lama Pidana yang dijatuhkan; d. Jenis Kejahatan, e. kriteria lainnya sesuai dengan kebutuhan atau perkembangan.

Ayat 2: Pembinaan Narapidana Wanita dilakukan di Lembaga Pemasyarakatan Wanita

Didalam Undang-undang Nomor 12 Tahun 1995 tentang Pemasyarakatan, ternyata masalah narapidana wanita tidak disebutkan pengaturannya. Karena yang disebutkan hanya narapidana, tidak dibedakan antara narapidana laki-laki maupun narapidana wanita, ini berarti telah terjadi kekosongan norma, sehingga kedepan hal ini perlu mendapat pengaturan norma antara narapidana laki-laki dan narapidana wanita tidak bisa diperlakukan sama, mengingat perbedaan fisik maupun psikologis antara laki-laki dan wanita.

Untuk mengakomodasi tempat khusus untuk menghukum atau membina Narapidana/Tahanan Wanita, maka Berdasarkan ketentuan Undang-undang nomor 12 Tahun 1995 pasal 1 dan 2, dibuatlah Lembaga Pemasyarakatan Khusus Wanita. Tujuan didirikan Lembaga Pemasyarakatan Khusus wanita tersebut adalah untuk memisahkan antara narapidana pria dan narapidana wanita dengan alasan faktor keamanan dan psikologis. Adapun cara pembinaan di Lembaga Pemasyarakatan wanita pada dasarnya tidak jauh berbeda dengan lembaga pemasyarakatan pada umumnya. Hanya sedikit kekhususan, dimana Lembaga Pemasyarakan Wanita lebih banyak diberikan keterampilan, misalnya menjahit, menyulam, dan memasak yang identik dengan pekerjaan wanita sehari-hari. Selain itu Lembaga Pemasyarakatan Wanita memberikan cuti haid bagi narapidanya yang mengalami menstruasi. Dalam hal melakukan pekerjaan, narapidana wanita diberikan pekerjaan yang relatif lebih ringan jika dibandingkan dengan narapidana laki-laki.

Dari uraian latar belakang di atas, maka dapat dijabarkan beberapa permasalahan penelitian sebagai berikut:

1. Bagaimanakah model pembinaan terhadap Narapidana Wanita di Lembaga Pemasyarakatan?

2. Faktor apa Saja yang menjadi Penghambat pelaksanaan pembinaan Narapidana Wanita dan Upaya-upaya apa saja yang dilakukan oleh Lembaga Pemasyarakatan Kelas IIB Dompu dalam mengatasi hambatanhambatan yang dihadapi?

Teori hukum yang digunakan untuk menganilisis permasalahan dalam penelitian ini adalah sebagai berikut:

Teori Keadilan

Teori Keadilan Adam Smith.

Alasan Adam Smith hanya menerima satu konsep atau teori keadilan adalah: keadilan 
sesungguhnya hanya punya satu arti yaitu keadilan komutatif yang menyangkut kesetaraan, keseimbangan, keharmonisan hubungan antara satu orang/ pihak dengan orang/pihak yang lain.

Teori Keadilan Distributif John Rawls

Beberapa konsep keadilan yang dikemukakan oleh John Rawls diakhir abad ke-20, seperti a Theory of justice, Politcal Liberalism, dan The Law of Peoples, yang memberikan pengaruh pemikiran cukup besar terhadap diskursus nilai-nilai keadilan.

\section{Teori Keadilan Menurut Aristoteles}

Aristoteles mengemukakan bahwa ada 5 jenis perbuatan yang tergolong dengan adil. keadilan yang dikemukakan adalah sebagai berikut: Keadilan Komutatif, Keadilan Distributif. Keadilan Kodrat Alam, Keadilan Konvensional. Keadilan Perbaikan.

Teori keadilan berdasarkan pandangan Pancasila

Pandangan keadilan dalam hukum nasional bersumber pada dasar negara. Pancasila sebagai dasar negara atau falsafah negara (fiolosofische grondslag) sampai sekarang tetap dipertahankan dan masih tetap dianggap penting bagi negara Indonesia. Menurut Kahar Masyhur dalam bukunya mengemukakan pendapat-pendapat tentang apakah yang dinamakan adil, terdapat tigal hal tentang pengertian adil.

(1) "Adil" ialah: meletakan sesuatu pada tempatnya.

(2) "Adil” ialah: menerima hak tanpa lebih dan memberikan orang lain tanpa kurang.

(3) "Adil" ialah: memberikan hak setiap yang berhak secara lengkap tanpa lebih tanpa kurang antara sesama yang berhak dalam keadaan yang sama, dan penghukuman orang jahat atau yang melanggar hukum, sesuai dengan kesalahan dan pelanggaran”.

Teori Pemidanaan

Teori Absolut atau Teori Pembalasan (Retribution Theory)

Menurut teori ini, pidana dijatuhkan karena orang telah melakukan suatu kejahatan atau tindak pidana (qui peccantum est). Pidana merupakan akibat mutlak yang harus ada sebagai suatu pembalasan kepada orang yang melakukan kejahatan.
Teori Pencegahan

Menurut teori ini, memidana bukanlah untuk memuaskan tuntutan absolut dari keadilan. Pembalasan itu sendiri tidak mempunyai nilai, tetapi hanya sebagai sarana untuk melindungi kepentingan masyarakat. Pidana bukanlah sekedar untuk melakukan pembalasan terhadap orang-orang yang telah melakukan tindak pidana, akan tetapi mempunyai tujuan tertentu yang lebih bermanfaat.

Teori Rehabilitasi

Dijatuhkannya hukuman kepada pelaku kejahatan, tidak saja dilihat sebagai suatu balasan atas perbuatan yang merugikan atau penjeraan semata, pelaksanaannya bukan pidana badan, akan tetapi pidana hilang kemerdekaan, tujuannya adalah memperbaiki pelaku kejahatan agar dapat berprilaku sewajarnya dan pantas dengan menanamkan norma-norma yang berlaku di masyarakat.

Teori Gabungan (Integratif Theory)

Muladi mengkategorikan tujuan pemidanaan ke dalam 4 (empat) tujuan, antara lain:

a) Pencegahan (umum dan khusus).

b) Perlindungan Masyarakat,

c) Memelihara Solidaritas Masyarakat,

d) Pidana bersifat Pengimbangan.

Teori Hukum Feminis (Feminist Legal Teori)

Feminis Legal Theory muncul sekitar Tahun 1970-an. Teori hukum feminis menyatakan bahwa, keberlakuan hukum semata-mata dipandang dari sudut laki-laki, dengan maksud bahwa hukum adalah milik laki-laki, laki-laki yang menyusun hukum dan teori hukum, dan selanjutnya hukum dan hasil putusannya merefleksikan nilai Laki-laki Teori feminis melihat dunia dari sudut pandang perempuan. Teori Feminis adalah sistem gagasan umum dengan cakupan luas tentang kehidupan sosial dan pengalaman manusia yang berkembang dari perspektif yang berpusat pada perempuan. Dalam perjalanan sejarahnya, teori feminis secara konstan bersikap kritis terhadap tatanan sosial yang ada dan memusatkan perhatiannya pada variabel-variabel sosiologi esensial seperti ketimpangan sosial, perubahan sosial, 
kekuasaan, institusi politik, keluarga, pendidikan, dll.

\section{METODE PENELITIAN}

Penelitian ini adalah termasuk Penelitian Yuridis Empiris, yaitu suatu metode penelitian hukum yang berfungsi untuk melihat hukum dalam artian nyata dan meneliti bagaimana bekerjanya hukum dilingkungan masyarakat. Metode Penelitian Hukum Yuridis Empiris dikatakan juga Penelitian sosiologi hukum karena untuk melihat aspek-aspek hukum dalam interaksi sosial didalam masyarakat, dan berfungsi sebagai penunjang untuk mengidentifikasi dan mengklarifikasi temuan bahan non hukum bagi keperluan penelitian atau penulisan hukum. Pendekatan yang digunakan dalam Penelitian ini: (1) Pendekatan Undang-undang (Statute Approacht).

Pendekatan Konsep (Koncep Approacht),

Pendekatan Kasus (Case Approacht), dan (4) Pendekatan Sosiologis (Sociologis Approacht).

\section{Pembahasan}

\section{Gambaran Umum Lembaga Pemasyarakatan Kelas IIB Dompu}

Secara formal Lembaga Pemasyarakatan Kelas IIB Dompu mulai beroperasi pada Tahun 1980 dengan bangunan kantor berlantai dua seluas $36.000 \mathrm{~m} 2$ yang berdiri diatas lahan seluas $40.500 \mathrm{~m} 2$ yang mulai dibangun Tahun 1978 artinya bangunan tersebut bukan peninggalan pemerintah kolonial Belanda melainkan buah karya bumi putra. Menurut data dan informasi pada awalnya Lembaga Pemasyarakatan Kelas IIB Dompu merupakan lahan pertanian Rumah Tahanan Negara Raba-Bima yang berada daerah Dompu. Secara geografis Lapas Dompu terletak di lereng perbukitan Desa Nowa, Kecamatan Woja, Kabupaten Dompu provinsi Nusa Tenggara Barat dengan Kondisi tanah yang berbukit dengan kemiringan 20-30 cm dengan karakteristik tanah jenis lilin yang labil dengan ciri khasnya pada musim panas pecah-pecah dan pada musim hujan becek dan rekat sehingga bangunan seringkali mengalami pergeseran yang mengakibatkan bangunan retak. Disebelah Barat berbatasan dengan areal persawahan milik Lapas, sebelah Timur dengan pemukiman penduduk, sebelah Utara berbatasan dengan Gunung Nowa dan sebelah Selatan dengan Jalan Trans Lintas Sumbawa-Bima. Struktur bangunan dari LAPAS Kelas IIB Dompu yang terdiri dari, antara lain:

1. Luas tanah : $40.500 \mathrm{~m} 2$

2. Luas bangunan: $3.600 \mathrm{M}^{2}$ dengan keadaan bangunan permanen yang dikelilingi oleh tembok lebih kurang 6 (enam) meter dan setiap sudut tembok mempunyai pos jaga, berjumlah 4 Pos.

Menurut penempatan pegawai pada masingmasing unit kerja (Staffing) dapat dilihat pada tabel berikut:

Tabel 1: Penempatan Pegawai LAPAS

\begin{tabular}{|c|c|c|}
\hline No & Satuan Unit Kerja & Jumlah \\
\hline 1 & Ka Lapas & 1 orang \\
\hline 2 & Sub Bagian Tata Usaha & 13 orang \\
\hline 3 & Ka.KPLP & 4 orang \\
\hline 4 & Binadik dan Giatja & 14 orang \\
\hline 5 & Adm. Kamtib & 5 orang \\
\hline 6. & Penjagaan dan P2U & 26 orang \\
\hline & Jumlah & 63 orang \\
\hline
\end{tabular}

Tabel 2: Kapasitas Penghuni Lapas per Mei 2016

\begin{tabular}{|c|c|c|c|c|}
\hline No & Golongan & $\mathrm{P}$ & $\mathrm{W}$ & Jumlah \\
\hline \multicolumn{5}{|c|}{ Narapidana } \\
\hline 1 & Pidana mati & - & - & \\
\hline 2 & Seumur hidup & - & - & \\
\hline 3 & B.I & 135 & 6 & 141 \\
\hline 4 & B.IIA & 12 & 3 & 15 \\
\hline 5 & B.IIB & - & - & - \\
\hline 6 & B.III & 3 & - & 3 \\
\hline \multirow[t]{2}{*}{7} & B.IIIS & & & \\
\hline & Jumlah & 150 & 9 & 159 \\
\hline \multicolumn{5}{|c|}{ Tahanan } \\
\hline 1 & A.I & - & 2 & - \\
\hline 2 & A.II & 4 & 1 & 5 \\
\hline 3 & A III & 41 & 5 & 46 \\
\hline 4 & A IV & 1 & - & 1 \\
\hline 5 & A V & - & - & \\
\hline & Jumlah & 46 & 8 & 54 \\
\hline
\end{tabular}

Sumber Data: Lembaga Pemasyarakatan Kelas IIB Dompu NTB Tahun 2016 
Tabel 4: Nama-nama Narapidana Wanita dan Jenis Kejahatan

\begin{tabular}{clll}
\hline No & \multicolumn{1}{c}{ Nama } & \multicolumn{1}{c}{ Pasal } & \multicolumn{1}{c}{ Tindak Pidana / Lama Pidana } \\
\hline 1 & Siti Hajar Aksa & 340 KUHP & Pembunuhan Berencana/14 Tahun \\
\hline 2 & Siti Rugaya & 338 KUHP & Pembunuhan / 11 Tahun \\
\hline 3 & Nunung Nurhayati & UU No.20 Tahun 2001 & Tindak Pidana Korupsi / 4 Tahun \\
\hline 4 & Fitriani Alias Fitri & UU No.35 Tahun 2009 & Narkotika dan Psikotropika/ 4 Tahun \\
\hline 5 & Riana Alias Ria & UU No.35 Tahun 2009 & Narkotika dan Psikotropika/ 5 Tahun \\
\hline 6 & Ayu Andira Alias Ayu & UU No.35 Tahun 2009 & Narkotika dan Psikotropika/ 4 Tahun \\
\hline 7 & Sarfiah & 363 KUHP & Pencurian dengan Pemberatan/7 Bulan \\
\hline 8 & Nuraeni & UU No.42 Tahun 1999 & Pengalihan benda yang menjadi objek Fidusia / \\
\hline 9 & Ernawati & UU No.35 Tahun 2009 & Narkotika dan Psikotropika/ 1 Tahun \\
\hline 10 & Hafsah & 303 KUHP & Perjudian / 9 Bulan \\
\hline 11 & Ferawati & UU No.35 Tahun 2009 & Narkotika dan Psikotropika/ 4 Tahun \\
\hline 12 & Desi Susanti & UU No.35 Tahun 2009 & Narkotika dan Psikotropika/ 4 Tahun \\
\hline 13 & Nurhasanah & UU No.39 Tahun 2004 & Penempatan dan Perlindungan Tenaga Kerja di \\
\hline 14 & Tati Sulianti & 362 KUHP Negeri / 9 Bulan \\
\hline 15 & Ririn Afriani & 372 KUHP & Pencurian / 7 Bulan \\
\hline 16 & Bunga Mawarni & UU No.35 Tahun 2009 & Narkotika dan Psikotropika/ 4 Tahun \\
\hline 17 & Irfani alias Iin & UU No.35 Tahun 2009 & Narkotika dan Psikotropika/ 3 Tahun \\
\hline & & Sumber Data: Lembaga Pemasyarakatan Kelas IIB Dompu NTB Tahun 2016
\end{tabular}

Model Pembinaan terhadap Narapidana Wanita di Lembaga Pemasyarakatan

Di lembaga pemasyarakatan Kelas IIB Dompu menerapkan model pembinaan narapidana berdasarkan Undang-Undang No. 12 Tahun 1995 tentang Pemasyarakatan yang menyatakan bahwa, sistem pembinaan pemasyarakatan dilaksanakan berdasarkan asas: a) Pengayoman; b) Persamaan perlakuan dan pelayanan; c) Pendidikan; d) Pembimbingan; e) Penghormatan harkat dan martabat manusia; f) Kehilangan kemerdekaan merupakan satu-satunya penderitaan; g) Terjaminnya hak untuk tetap berhubungan dengan keluarga dan orang-orang tertentu.

Dalam kegiatan Pembinaan yang dilakukan terhadap Narapidana Wanita di Lapas Kelas IIB Dompu dapat dibagi ke dalam 2 (dua) bidang yakni:

Pembinaan Kepribadian yang meliputi, antara lain:

Pembinaan Kesadaran Beragama.

Usaha ini dilakukan agar narapidana dapat tersentuh hatinya dengan siraman keagamaan terutama memberikan pengertian agar Warga Binaan Pemasyarakatan dapat menyadari akibatakibat dari perbuatan-perbuatan yang benar dan perbuatan-perbuatan yang salah. Menurut Bapak Hermanturi, S.Sos (Kasi Binadik dan Keg. Kerja), penerapan pembinaan tersebut dilakukan dengan cara mengadakan pengajian dan Siraman Rohani. Jadwal kegiatan tersebut dilakukan disetiap Hari Jum'at.

Pembinaan Berbangsa dan Bernegara.

Usaha ini dilaksanakan melalui Pendidikan Pancasila termasuk menyadarkan para narapidana agar dapat menjadi warga negara yang baik dapat berbakti kepada bangsa dan negaranya. Berdasarkan hasil wawancara dengan Bapak Hermanturi, S.Sos (Kasi Binadik) Lapas Kelas IIB Dompu, penerapan pembinaan tersebut dilakukan dengan cara-cara yang antara lain adalah dengan dilakukannya apel setiap harinya upacara bendera setiap hari senin dan setiap hari-hari besar Nasional dan hari LAPAS Pembinaan kemampuan intelektual (kecerdasan).

Pembinaan intelektual (kecerdasan) dapat dilakukan baik melalui pendidikan formal maupun melalui pendidikan non-formal. Berdasarkan hasil wawancara dengan Bapak Hermanturi, S.Sos, Pendidikan formal diselenggarakan sesuai dengan ketentuanketentuan yang telah ada yang ditetapkan oleh pemerintah agar meningkatkan kualitas warga 
binaan pemasyarakatan. Sedangkan pendidikan non-formal diselenggarakan sesuai dengan kebutuhan dan kemampuan melalui kursuskursus, latihan keterampilan, dsb.

Pembinaan Kesadaran Hukum.

Dilaksanakan dengan memberikan penyuluhan hukum yang bertujuan untuk mencapai kadar kesadaran hukum yang tinggi, sehingga sebagai anggota masyarakat narapidana menyadari akan hak dan kewajibannya dalam rangka turut menegakkan hukum dan keadilan, perlindungan terhadap harkat dan martabat manusia, ketertiban, ketentraman, kepastian hukum. Berdasarkan hasil wawancara dengan Bapak Syarif Hidayat, Bc.Ip,SH.MH (Ka Lapas Dompu), penyuluhan hukum bertujuan lebih lanjut untuk membentuk Keluarga Sadar Hukum (selanjutnya disebut KADARKUM) yang dibina selama berada dalam lingkungan pembinaan maupun setelah berada kembali di tengah-tengah masyarakat. Penyuluhan hukum diselenggarakan oleh Bagian Hukum Pemkab Dompu, Kejaksaan Negeri, Kepolisian, Pengadilan Negeri, Dinas Kesehatan Dompu, dan pihak Lembaga Swadaya Masyarakat (selanjutnya disebut LSM) secara langsung, hal tersebut juga dibenarkan oleh Nurhasanah (NAPI Wanita), biasanya penyuluhan hukum tersebut tentang masalah narkoba, HIV/AIDS, kesadaran hukum, dan sebagainya.

Pembinaan mengintegrasikan diri dengan Masyarakat.

Pembinaan di bidang ini dapat dikatakan juga sebagai pembinaan kehidupan sosial masyarakat, yang bertujuan pokok agar bekas narapidana wanita mudah diterima kembali oleh masyarakat. Berdasarkan hasil wawancara dengan Syarif Hidayat, Bc.Ip,SH.MH, untuk mencapai hal tersebut kepada mereka selama dalam Lembaga Pemasyarakatan dibina terus untuk patuh beribadah dan dapat melakukan usaha-usaha sosial secara gotong royong, sehingga pada waktu mereka kembali ke masyarakat mereka telah memiliki sifat-sifat positif untuk dapat berpartisipasi dalam pembangunan masyarakat di lingkungannya. Program integrasi diri dengan masyarakat. Namun untuk Program Asimilasi ini, dilembaga
Pemasyarakatan Kelas IIB Dompu belum menerapkannya walaupun Program Asimilasi tersebut merupakan bagian dari hak narapidana di setiap lembaga pemasyarakatan yang ada jika telah memenuhi ketentuan berdasarkan peraturan perundang undangan yang berlaku. Hal tersebut terjadi dikarenakan masih ada kekhawatiran dari pihak petugas di Lembaga Pemasyarakatan Kelas IIB Dompu jika narapidana yang bersangkutan tidak dapat diterima ataupun kurang mendapat perlakuan yang baik dari masyarakat luar, sehingga berpengaruh pada psikologis Narapidana Wanita tersebut. Hal ini juga dibenarkan oleh seluruh Narapidana Wanita, yang diwakilkan kepada Ibu Nunung Nurhayati, bahwa selama berada dalam Lapas, belum pernah ada bentuk kegiatan Asimilasi Keluar, dengan alasan Keamanan dan pandangan miring masyarakat terhadap Narapidana ataupun Tahanan, terutama Narapidana dan Tahanan Wanita.

Pembinaan kemandirian diberikan melalui program-program yaitu: a) Keterampilan untuk mendukung usaha mandiri. Keterampilan tersebut misalnya kerajinan tangan seperti menyulam atau menjahit, industri rumah tangga seperti Masak-memasak, membuat aneka macam kue, Keterampilan Salon Kecantikan dan sebagainya; b) Keterampilan untuk mendukung usaha industri kecil. Berdasarkan hasil wawancara dengan Bapak Syarif Hidayat, Bc.Ip,SH.MH, keterampilan tersebut misalnya pengelolaan bahan mentah dari sektor pertanian dan bahan alam menjadi bahan setengah jadi dan bahan jadi, contohnya membuat tikar, topi dan tas dari pandan yang dibimbing dari pihak LSM dan Ibu-ibu PKK. Untuk huruf a dan b, berdasarkan wawancara dengan Ibu Sarfiah (Napi Wanita), kegiatan yang dimaksud pada awalnya sering kali dilakukan dengan fasilitas dari Pihak Lapas sendiri yang menghadirkan Ibuibu PKK dari wilayah yang berada disekitar Lapas untuk mengadakan kegiatan yang dimaksud; c) Keterampilan yang dikembangkan sesuai dengan bakat para narapidana masingmasing. Hal tersebut belum dapat direalisasikan karena belum cukupnya sarana dan prasarana yang ada. Wawancara dengan Ibu Bunga 
Mawarni, bahwa setiap individu mempunyai bakat masing-masing yang berbeda dan ditambah lagi sarana dan prasarana yang tidak memadai.

Adapula kekhususan model Pembinaan yang tidak diatur dalam peraturan yang telah disebutkan diatas, misalnya: di Lembaga Pemasyarakatan Kelas IIB Dompu kadang kala Narapidana dan Tahanannya di ikut sertakan dalam kegiatan-kegiatan bercocok Tanam dan beternak yang merupakan usaha produktif yang dilakukan oleh LAPAS Kelas IIB Dompu. Berdasarkan hasil wawancara dengan Bapak Hermanturi S.Sos, pada penelitian yang dilakukan, ada perbedaan antara pembinaan yang dilakukan terhadap Narapidana dan Tahanan Wanita di LAPAS Dompu. Dimana untuk Narapidana Wanita, pembinaan yang dilakukan telah diuraikan seperti diatas, sedangkan untuk pembinaan terhadap Tahanan tidak seperti model pembinaan terhadap Narapidana, ini disebabkan karena Tahanan Wanita adalah merupakan individu yang masih menjalani pemeriksaan yang ditempatkan dalam LAPAS guna menunggu proses persidangan. Tahanan juga ada yang menjadi titipan dari Rumah Tahanan dan Lapas lain, jika ada yang diikut sertakan dalam pembinaan bersama dengan Narapidana tidak lebih karena mereka merupakan partisipan disebabkan karena model pembinaan yang dilakukan bersifat positif dan juga terdorong pada kesamaan ruangan dengan Narapidana Wanita yang lain, dimana di Lapas Kelas IIB Dompu Blok Narapidana/Tahanan Wanita hanya 1 (satu) ruangan saja. Khusus bagi para tahanan, kegiatan yang diberikan kepada mereka bukan hanya semata-mata dimaksudkan sebagai kegiatan pengisi waktu agar terhindar dari pemikiran-pemikiran yang negatif (seperti berusaha melarikan diri), tetapi harus lebih dititikberatkan pada penciptaan kondisi yang dapat melancarkan jalannya proses pemeriksaan perkaranya di Pengadilan.

Setelah melihat model pembinaan yang dilakukan Lembaga Pemasyarakatan Kelas IIB Dompu, maka model pembinaan tersebut sesuai dengan teori-teori tentang pemidanaan yang sebagaimana telah diutarakan sebelumnya dalam kerangka teori. Jadi teori yang dipergunakan dalam Model Pembinaan di Lembaga Pemasyarakatan Kelas IIB Dompu adalah Teori Pembalasan (Absolut), ini dapat dilihat dari tindakan dan sanksi hukum yang diberikan kepada beberapa Narapidana yang melakukan tindakan pidana yang di jatuhi hukuman berat (Vonis Pidana 4 sampai dengan 14 Tahun), dimana tujuan diberikan sanksi pidananya adalah agar mereka merasakan bagaimana tersiksanya hukuman dengan dihukum hilang kemerdekaan dalam waktu yang sangat lama dengan tujuan agar mereka menyadari dan jera akan perbuatan yang dilakukan.

Jika dilihat dari model pembinaan terhadap Narapidana Wanita yang telah diuraikan, juga berkaitan dengan Teori Pencegahan, Maksudnya teori pencegahan sesuai dengan model pembinaan Narapidana di Lembaga Pemasyarakatan Kelas IIB Dompu karena penjatuhan hukuman bagi para narapidana sebagai upaya membuat efek jera yang berguna untuk mencegah terulangnya kembali tindak kejahatan yang mereka perbuat sebelumnya.

Sedangkan maksud Teori Rehabilitasi sesuai dengan model pembinaan narapidana di Lembaga Pemasyarakatan Kelas IIB Dompu karena memang penempatan seseorang yang dikatakan sebagai narapidana di tempat tertentu yang dalam hal ini lembaga Pemasyarakatan Kelas IIB Dompu dengan maksud membatasi kemerdekaan seseorang yang bertujuan untuk memperbaiki pelaku kejahatan agar berperilaku wajar dan pantas dengan mencantumkan normanorma yang berlaku di masyarakat atau dapat dikatakan merehabilitasi perilaku dari pelaku tindak kejahatan atau narapidana.

Berdasarkan hasil penelitian yang dilakukan oleh penulis, adapun dampak yang timbul dari model pembinaan yang dilakukan oleh Lembaga Pemasyarakatan Kelas IIB Dompu, antara lain:

Dampak Positif: a) Diadakannya pembinaan beragama bagi para narapidana yang tidak pandai sholat, menjadi pandai dan paham tentang sholat yang baik dan benar; b) Bagi narapidana yang tidak pandai mengaji, setelah keluar dari Lembaga Pemasyarakatan Kelas IIB Dompu menjadi pandai mengaji bahkan dapat mengajar mengaji untuk orang lain setelah yang 
bersangkutan keluar dari Lapas Dompu; c) Bagi narapidana yang buta huruf, menjadi bisa membaca dan menulis; d) Menyadari segala kesalahan yang telah diperbuat selama ini adalah perbuatan dosa dan menyesali segala perbuatannya; e) Diadakannya pembinaan kemandirian seperti menjahit, menyulam, membuat kue kering/basah, salon dan sebagainya.

Dampak Negatif: a) Diadakannya pembinaan dalam hal penerimaan Remisi setiap hari besar agama (remisi khusus) dan remisi umum setiap Tanggal 17 Agustus serta pengajuan pembebasan bersyarat, cuti menjelang bebas, cuti bersyarat dan asimilasi, maka cara narapidana merasa hukuman menjadi tidak terasa; b) Berhubung karena pembinaan kemandirian hanya itu-itu saja membuat para narapidana tersebut merasa bosan dan menganggap hanya untuk mengisi waktu saja; c) Adanya narapidana yang dipekerjakan untuk membantu petugas dalam melakukan pekerjaan dan terkadang diberikan upah. Sehingga narapidana tersebut merasa enak dan tidak merasa sakit berada di Lembaga Pemasyarakatan; d) Adanya perubahan sistim kepenjaraan ke sistim pemasyarakatan yang membawa dampak demokrasi pembinaan yang mengedepankan Hak Asasi Manusia. Narapidana menjadi kurang menghargai Petugas/Pegawai LAPAS) dan petugas/pegawai LAPAS terlalu berhati-hati dalam menindak narapidana yang melakukan pelanggaran karena apabila perlakuan diberikan sedikit keras, maka akan mendapatkan sanksi dari atasan (KA LAPAS).

Faktor Penghambat pelaksanaan pembinaan Narapidana Wanita dan Upaya-upaya yang dilakukan oleh Lembaga Pemasyarakatan Kelas IIB Dompu dalam mengatasi Hambatan yang dihadapi

Faktor Penghambat Pelaksanaan Pembinaan Narapidana Wanita

Ada 2 (dua) faktor Penghambat Pembinaan NaPIa Wanita, yaitu:

Faktor-Faktor Interen: a) Sarana gedung lembaga pemasyarakatan; b) Kualitas dan kuantitas petugas; c) Kesejahteraan Petugas; d) Sarana/Fasilitas Kesejahteraan; e) Anggaran
Lembaga Pemasyarakatan; f) Sumber Daya Alam; g) Kualitas dan Ragam Program Pembinaan.

Tabel 4. Jumlah Narapidana dan Tahanan di Lembaga Pemasyarakatan Kelas IIB Dompu NTB Tahun 2016

\begin{tabular}{|c|c|c|c|c|}
\hline No & Golongan & $\mathrm{P}$ & W & Jumlah \\
\hline \multicolumn{5}{|c|}{ Narapidana } \\
\hline 1 & Pidana mati & - & 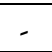 & \\
\hline 2 & Seumur hidup & - & - & \\
\hline 3 & B.I & 135 & 6 & 141 \\
\hline 4 & B.IIA & 12 & 3 & 15 \\
\hline 5 & B.IIB & - & - & - \\
\hline 6 & B.III & 3 & - & 3 \\
\hline \multirow[t]{2}{*}{7} & B.IIIS & & & \\
\hline & Jumlah & 150 & 9 & 159 \\
\hline \multicolumn{5}{|c|}{ Tahanan } \\
\hline 1 & A.I & - & - & - \\
\hline 2 & A.II & 4 & 3 & 7 \\
\hline 3 & A III & 41 & 5 & 46 \\
\hline 4 & A IV & 1 & - & 1 \\
\hline \multirow[t]{2}{*}{5} & A V & - & - & \\
\hline & Jumlah & 46 & 8 & 54 \\
\hline
\end{tabular}

Sumber Data: LP Kelas IIB Dompu NTB 2016

Tabel 5. Jumlah Narapidana dan Tahanan Wanita 4 Tahun terakhir di Lapas Kelas IIB Dompu

\begin{tabular}{ccc}
\hline No & Tahun & Jumlah Tahanan \\
\hline 1 & 2013 & 12 \\
\hline 2 & 2014 & 13 \\
\hline 3 & 2015 & 14 \\
\hline 4 & 2016 & 17 \\
\hline
\end{tabular}

Sumber Data: LP Kelas IIB Dompu NTB (Tahun 2013. 2016)

Tabel 6. Latar belakang Pendidikan Petugas/Pegawai Lembaga Pemasyarakatan Kelas IIB Dompu NTB Tahun 2016

\begin{tabular}{clc}
\hline No & \multicolumn{1}{c}{ Pendidikan } & Jmlh \\
\hline 1 & Sekolah Dasar SD) & - \\
\hline 2 & Sekolah Menengah Pertama (SMP) & - \\
\hline 3 & Sekolah Menengah Atas (SMA) & 32 \\
\hline 4 & Sekolah Menengah Kejuruan (SMK) & 2 \\
\hline 5 & Diploma-3 (D3) & 2 \\
\hline 6 & Sarjana/Srtata-1 (S1) & 26 \\
\hline 7 & Strata-2 (S2) & 1 \\
\hline & Jumlah & 63 \\
\hline
\end{tabular}

Sumber Data: Lembaga Pemasyarakatan Kelas IIB Dompu NTB Tahun 2016

Tabel 7. Jumlah Petugas/Pegawai di LP Dompu yang pernah Mengikuti Pelatihan.

\begin{tabular}{cccc}
\hline No & \multicolumn{1}{c}{ Jenis Pelatihan } & Pria & Wanita \\
\hline 1 & Petugas Kemasyarakatan & 3 & - \\
\hline 2 & Samapta & 60 & 3 \\
\hline
\end{tabular}




\begin{tabular}{clcc}
\hline 3 & Narkoba & 12 & 3 \\
\hline 4 & Bimbingan Hukum & 14 & 3 \\
\hline 5 & Pelayanan Masyarakat & 24 & 3 \\
\hline 6 & Perawatan Kesehatan & 3 & 1 \\
\hline
\end{tabular}

Sumber Data: LP Kelas IIB Dompu (Tahun 2015-2016)

Faktor Eksteren: a) Faktor Ekonomi; b) Faktor Pendidikan.

Tabel 8. Tingkat Pendidikan Narapidana Wanita di Lembaga Pemasyarakatan Kelas IIB Dompu NTB Tahun 2016

\begin{tabular}{clc}
\hline No & \multicolumn{1}{c}{ Pendidikan } & Jmlh \\
\hline 1 & Buta Huruf & 1 \\
\hline 2 & Sekolah Dasar (SD) & 2 \\
\hline 3 & Sekolah Menengah Pertama (SMP) & 5 \\
\hline 4 & Sekolah Menengah Atas (SMA) & 8 \\
\hline 5 & Sekolah Menengah Kejuruan (SMK) & - \\
\hline 6 & Diploma-3 (D3) & - \\
\hline 7 & Sarjana/Srtata-1 (S1) & 1 \\
\hline 8 & Strata-2 (S2) & - \\
\hline & Jumlah & 17 \\
\hline
\end{tabular}

Sumber data: LP Kelas IIB Dompu NTB Tahun 2016 Upaya-Upaya yang dilakukan oleh Lembaga Pemasyarakatan Kelas IIB Dompu dalam mengatasi Hambatan-Hambatan yang terjadi

Upaya yang dilakukan berkaitan dengan Kebijakan: a) Reformasi dalam Proses Kebijakan Pemasyarakatan. Hal ini terkait dengan komitmen penuh Direktorat Jenderal Pemasyarakatan (Dirjen Pemsy) untuk mengambil kebijakan yang langsung tertuju pada penanggulangan yang mendesak adalah masalah kapasitas Lembaga Pemasyarakatan: b) Reformasi dalam sistem pembinaan narapidana dengan membuat metode pemanfaatan waktu luang agar lebih bermanfaat bagi narapidana dan Lembaga Pemasyarakatan dengan menciptakan kegiatankegiatan bagi narapidana yang lebih produktif dengan mengisi sebagian besar waktu mereka selama berada dalam lembaga pemasyarakatan agar mereka mampu menurunkan deprivasi (penderitaan) psikologis yang dialami narapidana, serta perlunya memperhatikan mekanisme reward dan punishment; c) Reformasi Paradigmatik pemasyarakatan harus dikembalikan konsepsi dasarnya sebagai upaya reintegratif atau mengintegrasikan kembali pelaku kejahatan dengan masyarakatnya setelah menjadi konflik berupa kejahatan.
Hambatan-hambatan yang terjadi di Lembaga Pemasyarakatan Kelas IIB Dompu harus diatasi dengan berbagai cara untuk dapat menuju suatu pembaruan sistem pemasyarakatan antara lain: 1) Pembenahan SDM, dalam hal ini petugas atau Pegawai LAPAS Kelas IIB Dompu yang berawal dari proses rekruitmen/penerimaan untuk petugas/pegawai LAPAS; 2) Efektifisasi pengklasifikasian narapidana baik dari segi umur, jenis kelamin, jenis tindak pidana dan lamanya pidana yang dijalani; 3) Pemberian motivasi kepada narapidana bahwa dalam melaksanakan program-program yang telah ditentukan disetiap LAPAS yang ada di Indonesia; 4) Terhadap petugas atau Pegawai LAPAS Kelas IIB Dompu yang berpendidikan Sarjana, maka diharapkan lebih diberdayakan lagi dalam pembinaan Narapidana dalam program-program kemandirian; 5) Terhadap Tim Pelatihan yang ada di LAPAS, agar memberikan masukan kepada Ka LAPAS untuk mengadakan kerjasama dengan pihak industri Kecil disekitar LAPAS; 6) Pihak Petugas/Pegawai LAPAS harus lebih optimal atau lebih sering melakukan pendekatan per individu ataupun kelompok-kelompok untuk memberikan pengarahan-pengarahan yang bersifat positif.

Upaya-Upaya yang Dilakukan oleh Lembaga Pemasyarakatan Kelas IIB Dompu NTB dalam Mengatasi Over Capacity; a) Mengajukan permohonan untuk merenovasi atau memperbaharui bangunan yang sudah ada; 7) Mengurangi atau membatasi narapidana ke lembaga pemasyarakatan/rumah tahanan negara. Hal-hal yang dapat dilakukan melalui program antara lain yaitu: 1) Mengintensifkan bentuk Tahanan Rumah dan Tahanan Kota, kegiatan ini dapat dilakukan dalam setiap tingkat Penahanan yaitu pada tingkat Penyidikan, tingkat Penuntutan dan tingkat Pemeriksaan oleh Pengadilan. Bentuk penahanan rumah dan penahanan Kota ini secara tegas diatur dalam pasal 22 ayat (1) KUHAP; 2)Mengintensifkan bentuk penjatuhan Hukuman Pidana Bersyarat; 3) Mengintensifkan Pemberian Pidana Denda sebagaimana yang diatur pasal 10 huruf a angka 4c KUHP; 4) Mengoptimalkan Pemanfaatan Hasil Penelitian 
Kemasyarakatan yang dilakukan oleh Balai Bapas; 5) Menyurati/menghubungi pihak kejaksaan agar segera mengirim putusan/vonis ke Lembaga Pemasyarakatan

\section{Mempercepat pengeluaran Narapidana.}

Proses pemasyarakatan narapidana akan berjalan efektif apabila narapidana diberikan kesempatan seluas-luasnya untuk berinteraksi dan berbaur dengan masyarakat melalui Proses Asimilasi dan Integrasi.

\section{KESIMPULAN}

Pada dasarnya Model pembinaan narapidana Wanita yang dilakukan di lembaga pemasyarakatan Kelas IIB Dompu sama dengan Model Pembinaan di Lapas-lapas yang lain pada umumnya. Akan tetapi ada beberapa Pembinaan Khusus terhadap Narapidana Wanita di LAPAS Kelas IIB Dompu, yaitu: diikutsertakan dalam beberapa kegiatan yaitu, kegaiatan bercocok tanam, pertanian, dan kerja sama dengan industri Rumahan, pengajian dan siraman rohani yang dilakukan setiap hari Jumat.

Faktor-faktor yang menjadi penghambat berjalannya model pembinaan Narapidana di Lapas Kelas IIB Dompu antara lain, yaitu: Faktor Intern dan Faktor Ekstern. Upaya-upaya yang dilakukan oleh Lembaga Pemasyarakatan Kelas IIB Dompu dalam mengatasi hambatanhambatan yang terjadi, antara lain: Peningkatan Kualitas SDM, Rehabilitasi Bangunan atau Gedung LAPAS. Pengklasifikasian Narapidana, Mengurangi atau membatasi narapidana ke LAPAS/RUTAN, Mempercepat Pembebasan Bersyarat, Pemberian Remisi, dan pemindahan Napi/Tahanan ke Lapas yang masih sedikit Penghuninya

\section{DAFTAR PUSTAKA}

Bachtiar Agus Salim, Tujuan Pidana Penjara sejak reglemen 1917 hingga lahirnya Sistem Pemasyarakatan di Indonesia Dewasa ini, Pustaka Bangsa, Medan, 2003;

Bambang Waluyo, Penelitian Hukum dalam Praktek, Sinar Grafika, Jakarta 2002;

CJ. Harsono HS, Sistem baru Pembinaan Narapidana, Djambatan, Jakarta, 1995;

David J. Cooke, Pamela J. badwin dan Jaquilie.
Menyikap Dunia Gelap Penjara. PT. Gramedia

Pustaka Utama, Jakarta, 2008;

Dwidja Priyatno, Sistem Pelaksanaan Pidana Penjara di Indonesia. PT. Refika Aditama, Bandung, 2006;

Ilmi Bisri, sistem Hukum Indonesia: Prinsipprinsip dan Implementasi Hukum di Indonesia. Disertasi Program Pasca Sarjana. Fakultas Hukum Universitas Indonesia, 2001;

Kahar Masyhur, Membina Moral dan Akhlak, Kalam Mulia, Jakarta, 1985;

Muladi, Lembaga Pidana Bersyarat. Alumni, Bandung: 1985;

Peter Mahmud Marzuki, Penelitian Hukum Edisi Revisi, Kencana Prenada Media Goup, Surabaya, 2005;

Rodliyah, Pidana Mati terhadap Perempuan. Suatu

Kajian Perbandingan, Arti Bumi Intaran, Yogyakarta, 2014;

Roeslan Saleh, Perbuatan Pidana dan Pertanggungjawaban Pidana dua Pengertian Dasar dalam Hukum Pidana, Aksara Baru, Jakarta, 1983;

Sudarto, Hukum Pidana: Jilid I A , Badan Penyedia Kuliah Fakultas Hukum Universitas Diponegoro, Semarang, 1973

Soerjono Soekanto, Pengantar Penelitian Hukum, UI Press, Jakarta, 1986.

Widodo dan Wiwik Utami, Hukum Pidana $\mathcal{E}$ Penologi-Rekontruksi Model Pembinaan berbasis Kompetensi bagi terpidana Cybercrime, CV. Aswaja Pressindo, 2014.

Zainuddin Ali, Metode Penelitian Hukum, Sinar Grafika, Jakarta, 2009;

Muzakkir, Posisi Hukum Korban Kejahatan dalam sistem peradilan pidana Disertasi Program Pasca sarjana. Fakultas Hukum Universitas Islam Indonesia, 1993.

Muzakkir, Sistem Pengancaman Pidana dan Hukum Pidana, Makalah disampaikan pada Seminar Nasional Kriminalisasi dan Deskriminasi dalam Pembaharuan Hukum Pidana Indonesia, Fakultas Hukum Universitas Islam Indonesia. Juli 1993

Suara Pembaharuan, Reformasi Lembaga Pemasyarakatan, Tanggal 2 Agustus 2007, hal 10 
http://www. google-Tentang Teori Keadilan.

http://www.nicic.org.

http//:dewey/petra,ac.id

Undang-undang Nomor 12 Tahun 1995 tentang

Pemasyarakatan

Undang-undang Nomor 39 Tahun 1999 Tentang

Hak Azasi Manusia

Peraturan Pemerintah Nomor 31 Tahun 1999

Tentang Pembinaan dan Pembimbingan

Warga Binaan Pemasyarakatan

Keputusan Menteri Kehakiman Republik

Indonesia Nomor: M.02-PK.04.10 Tahun

1990 Tentang Pola Pembinaan Narapidana

Peraturan Menteri Hukum dan Hak Asasi

Manusia Republik Indonesia Nomor:

M.HH-02.PK.05.06 Tahun 2010 tentang

Perubahan Kedua atas Peraturan Menteri

Hukum dan Hak Asasi Manusia Republik

Indonesia Nomor M.01.PK.04.10 Tahun 2007

A. Syukur, S.Sos (Kasi Kamtib) LAPAS Kelas IIB Dompu

A. Azis, S.IP, (Kaur Umum) LAPAS Kelas IIB Dompu

Bunga Mawarni (NAPI Wanita) LAPAS Kelas IIB Dompu

Hermanturi, S.Sos (Kasi Binadik), LAPAS Kelas II B Dompu.

Misponiran (Kasubsi Keamanan) LAPAS Kelas II B Dompu

Muh. Akbar, A.Md.Kep (Pengelola Data Kesehatan) LAPAS Kelas IIB Dompu

Muh. Said, S.Sos (Kasubsi Perawatan) LAPAS Kelas IIB Dompu

Mustamin, ST (Kasubsi Reg dan Bimb Kemasy) LAPAS Kelas IIB Dompu

Nunung Nurhayati (NAPI Wanita) di Lapas Kelas IIB Dompu

Nurhasanah, (NAPI Wanita) di Lapas Kelas IIB Dompu

Sarfiah (NAPI Wanita) di Lapas Kelas IIB Dompu

Siti Hajar Aksa (Napi Wanita) di Lapas Kelas IIB Dompu

Syarif Hidayat, Bc.Ip., SH.MH (Ka Lapas Kelas II B Dompu) 